\title{
Layanan SMS Nilai Dengan Menggunakan Teori CRM Untuk Meningkatkan Pelayanan Mahasiswa
}

\author{
Robby Yuli Endra \\ Program Studi Teknik Informatika \\ Fakultas Ilmu Komputer \\ Universitas Bandar Lampung
}

Jln. Z.A. Pagar Alam No.26 Labuhan Ratu Bandar Lampung 35142

Telp. (0721) 701463, (0721) 701979 Fax. (0721) 701467 Web. www.ubl.ac.id

\begin{abstract}
Abstrak
Universitas Bandar Lampung merupakan salah satu lembaga swasta yang menyediakan jasa pendidikan bagi masyarakat. Universitas Bandar Lampung telah memiliki pengalaman dalam menyediakan jasa pendidikan selama 25 tahun dan memiliki komitmen untuk selalu memberikan yang terbaik bagi masyarakat dalam rangka untuk mencerdaskan masyarakat indonesia.

Penelitian ini akan menggambarkan serta menjelaskan kegiatan-kegiatan yang berhubungan dengan nilai di Universitas Bandar Lampung. Peneliti akan menggunakan teori CRM pada sistem layanan sms yang berhubungan dengan nilai. Penjelasan mengenai sistem layanan sms nilai dengan teori CRM akan dijelaskan pada bab IV penelitian ini.
\end{abstract}

Kata kunci : sms, CRM, nilai

\subsection{PENDAHULUAN}

Universitas Bandar Lampung merupakan badan usaha yang bergerak di bidang pendidikan. Universitas Bandar Lampung termasuk universitas terbaik di propinsi Lampung. Universitas Bandar Lampung memberikan berbagai layanan kepada para mahasiswanya, salah satunya adalah pada bagian akademik.

Pelayanan akademik yang diberikan kepada mahasiswa di Universitas Bandar Lampung antara lain, pelayanan pengisian KRS, pelayanan KHS dan transkrip, pelayanan bimbingan akademik, dan pelayanan pengelolaan nilai. Sistem akademik yang ada sekarang sudah cukup baik. Mahasiswa dapat melakukan pengisian KRS melalui komputer yang telah disediakan di laboratorium komputer. Untuk KHS dan transkrip, dapat diambil oleh mahasiswa pada akhir semester. Selain itu, mahasiswa akan mendapat bimbingan akademik dari dosen-dosen yang telah berpengalaman. Sedangkan untuk nilai, mahasiswa dapat mengaksesnya dari komputerkomputer yang telah disediakan.
Sayangnya, komputer untuk mengakses nilai hanya tersedia terbatas di gedung rektorat dan di laboratorium komputer. Sehingga, mahasiswa harus mengantri untuk mengakses melalui komputer yang disediakan di rektorat. Sedangkan untuk yang di laboratorium komputer, mahasiswa harus berjalan cukup jauh karena letaknya berada di lantai 3 gedung fakultas ilmu komputer.

\subsection{Identifikasi Masalah}

Dari latar belakang yang telah diungkapkan di atas dapat dilihat bahwa:

1. pada sistem akademik di Universitas Bandar Lampung sudah cukup

2. mahasiswa sering mengalami kesulitan dalam mengakses nilainya karena mahasiswa hanya dapat mengetahui nilainya dari Kartu Hasil Studi.

\subsection{Ruang Lingkup Masalah}

Melihat permasalahan tersebut, maka peneliti membatasi masalah yang akan dibahas dalam penelitian ini hanya pada sistem akademik, khususnya bagian nilai mahasiswa. 


\subsection{Perumusan Masalah}

Peneliti merumuskan permasalahan yang muncul adalah kurang efektifnya pemberitahuan nilai di Universitas Bandar Lampung.

"Apakah dengan layanan SMS dengan menggunakan teori CRM dapat meningkatkan pelayanan mahasiswa di Universitas Bandar Lampung?"

\subsection{Tujuan Penelitian}

Adapun penelitian penelitian ini memiliki tujuan sebagai berikut:

1. Untuk menguji teori CRM dalam meningkatkan pelayanan mahasiswa di Universitas Bandar Lampung.

2. Mempelajari teknologi mobile khususnya SMS gateway dan fitur auto reply.

\subsection{Manfaat Penelitian}

Adapun penelitian penelitian ini diharapkan dapat memberi manfaat, diantaranya :

1. Mempermudah dalam memberikan balasan SMS yang membutuhkan informasi tertentu.

2. Mendukung penggunaan teknologi SMS.

3. Memudahkan mahasiswa untuk mengetahui nilainya.

\section{LANDASAN TEORI}

\subsection{Definisi Otomatisasi}

Definisi Otomoatisasi adalah sebagai berikut:

1. Penggantian tenaga manusia dengan tenaga mesin yang secara otomatis melakukan dan mengatur pekerjaan sehingga tidak memerlukan lagi pengawasan manusia (dalam industri dsb)

2. Perihal otomatis; pengotomatisan (Kamus Besar Bahasa Indonesia)

\subsection{SMS(Short Message Service) \\ 2.2.1 Pengertian SMS}

Short Message Service (SMS) merupakan layanan komunikasi standar dalam sistem komunikasi selular GSM, menggunakan standar protokol komunikasi yang memungkinkan pertukaran pesan teks singkat antara perangkat telepon selular (Gil Held, 2001. Data over Wireless Network)

\subsubsection{Pengertian SMS Gateway}

SMS Gateway adalah sebuah perangkat atau layanan yang menawarkan SMS transit, transformasi pesan ke jaringan selular lalu lintas dari media lain, atau sebaliknya, yang memungkinkan pengiriman atau penerimaan pesan SMS dengan atau tanpa penggunaan telepon selular .

(Romzi Imron.R, 2006).

SMS Gateway merupakan sistem aplikasi untuk mengirim atau menerima SMS, terutama digunakan dalam aplikasi bisnis, baik untuk kepentingan promosi, servis kepada kustomer, pengadaan content produk atau jasa, dan seterusnya.

(PCMedia, 2008:86)

\subsubsection{Fitur-fitur SMS Gateway}

Beberapa fitur yang umum dikembangkan dalam aplikasi SMS Gateway adalah:

1. Auto-reply

SMS Gateway secara otomatis akan membalas SMS yang masuk. Contohnya adalah SMS Request.

2. Pengiriman missal

Disebut juga dengan istilah SMS broadcast, bertujuan untuk mengirimkan SMS ke banyak tujuan sekaligus.

3. Pengiriman terjadwal

Sebuah SMS dapat diatur untuk dikirimkan ke tujuan secara otomatis pada waktu tertentu. (PCMedia, 2008:86)

\subsubsection{Pengertian SMS Request}

SMS Request merupakan sebuah aplikasi SMS Server yang dapat digunakan sebagai media untuk meminta suatu informasi melalui SMS. (Adi Purnomo, 2007:196)

\subsection{Konsep Dasar Sistem}

Sistem adalah kumpulan dari elemen-elemen yang berinteraksi untuk mencapai suatu tujuan tertentu. (Jogiyanto, HM, 2005 : 2)

Menurut M.J Alexander dalam buku Information System Analysis : Theory and Application, sistem merupakan suatu group dari elemen-elemen baik yang berbentuk fisik maupun non-fisik yang menunjukkan suatu kumpulan yang saling berhubungan dan berinteraksi bersama-sama 
menuju satu atau lebih tujuan, sasaran atau akhir dari sebuah sistem. (Wahyono, Teguh, $2004: 12$ )

\subsection{Pengenalan Java Dan Java Netbeans 6.5 2.4.1 Pengenalan Java}

Java adalah sebuah bahasa pemrograman komputer berbasiskan kepada Object Oriented Programming. Java diciptakan setelah $\mathrm{C}++$ dan didesain sedemikian sehingga ukurannya kecil, sederhana, dan portable (dapat dipindahpindahkan di antara bermacam platform dan sistem operasi). Program yang dihasilkan dengan bahasa Java dapat berupa applet (aplikasi kecil yang jalan di atas web browser) maupun berupa aplikasi mandiri yang dijalankan dengan program Java Interpreter. Contoh program yang ditulis dengan bahasa Java adalah HotJava yang berupa sebuah web browser. Salah satu keunggulan Java adalah sifatnya yang 'platform independence', artinya Java - baik source program maupun hasil kompilasinya - sama sekali tidak bergantung kepada sistem operasi dan platform yang digunakan. Source code sebuah aplikasi dengan bahasa Java yang ditulis di atas sistem Windows NT misalnya, dengan gampang dapat dipindahkan ke sistem operasi UNIX tanpa harus mengedit satu baris kode-pun. Ini tentunya merupakan satu nilai tambah tersendiri. Bandingkan dengan bahasa $\mathrm{C} / \mathrm{C}++$ misalnya, jika kita bekerja pada UNIX FreeBSD dan ingin memindahkannya pada HP UNIX, kita terkadang harus juga mengedit source code-nya sehingga sesuai dengan HP UNIX, walaupun keduanya masih berada dalam keluarga UNIX.

Dan yang lebih hebat lagi, bukan hanya source code-nya saja yang bisa dipindah-pindahkan antar sistem komputer, bahkan hasil kompilasinya pun bisa dijalankan di berbagai sistem komputer. Hal ini dimungkinkan dengan adanya bytecode. Setiap program yang ditulis dengan bahasa Java, hasil kompilasinya berupa bytecode, yaitu sekumpulan instruksi yang kelihatannya seperti kode mesin (machine code) tapi tidak spesifik untuk satu jenis prosesor tertentu.

Umumnya jika kita menulis program -misalnya dalam bahasa $\mathrm{C}++-$ pada satu sistem komputer misalnya PC-, kompiler akan menterjemahkan source code kedalam bahasa mesin yang spesifik untuk prosesor yang ada di PC. Jika hendak dijalankan di sistem lain, Macintosh misalnya, maka source code harus dikompilasi lagi pada mesin Macintosh yang bersangkutan, dan terkadang harus melakukan pengeditan source code terlebih dahulu. Menjalankan hasil kompilasi dari platform Windows pada platform UNIX tidak akan pernah berhasil.

\section{(Onno W. Purbo \& Akhmad Daniel S, 1998)}

\subsubsection{Sejarah Netbeans}

Pengembangan NetBeans diawali dari Xelfi, sebuah proyek mahasiswa tahun 1997 di bawah bimbingan Fakultas Matematika dan Fisika Universitas Charles, Praha. Sebuah perusahaan kemudian dibentuk untuk proyek tersebut dan menghasilkan versi komersial NetBeans IDE hingga kemudian dibeli oleh Sun Microsystem pada tahun 1999. Sun kemudian menjadikan NetBeans open source pada bulan Juni tahun 2000. Sejak itu komunitas NetBeans terus berkembang.

\subsubsection{Pemahaman Netbeans 6.5}

Netbeans versi 6.5 adalah sebuah open source tool yang menggunakan bahasa pemograman Java yang dapat menghasilkan aplikasi untuk komputer desktop, ponsel, PDA, hingga aplikasi web. NetBeans mengacu pada dua hal, yakni platform untuk pengembangan aplikasi desktop java, dan sebuah Integrated Development Environment (IDE) yang dibangun menggunakan platform NetBeans.

Platform NetBeans memungkinkan aplikasi dibangun dari sekumpulan komponen perangkat lunak moduler yang disebut 'modul'. Sebuah modul adalah suatu arsip Java (Java archive) yang memuat kelas-kelas Java untuk berinetraksi dengan NetBeans Open API dan file manifestasi yang mengidentifikasinya sebagai modul. (Sri Hartati Wijono, B. Herry Suharto, Matius Soesilo Wijono, 2007 )

\subsection{Auto Reply \\ 2.5.1 Pengertian AutoReply}

Auto Reply adalah fitur yang memungkinkan pengiriman balasan secara otomatis, banyak digunakan untuk e-mail, biasa digunakan saat penerima sedang tidak ditempat .

\subsubsection{SMS Auto Reply}

SMS Auto Reply adalah layanan SMS yang memungkinkan komunikasi secara 2 arah dengan para pengirim. Dengan konsep, setiap kali pengirim mengirim SMS, pengirim tersebut akan 
menerima balasan secara otomatis. (PCMedia, 2008:86)

\section{Rancangan dan Implementasi 3.1Rancangan Menu Utama}

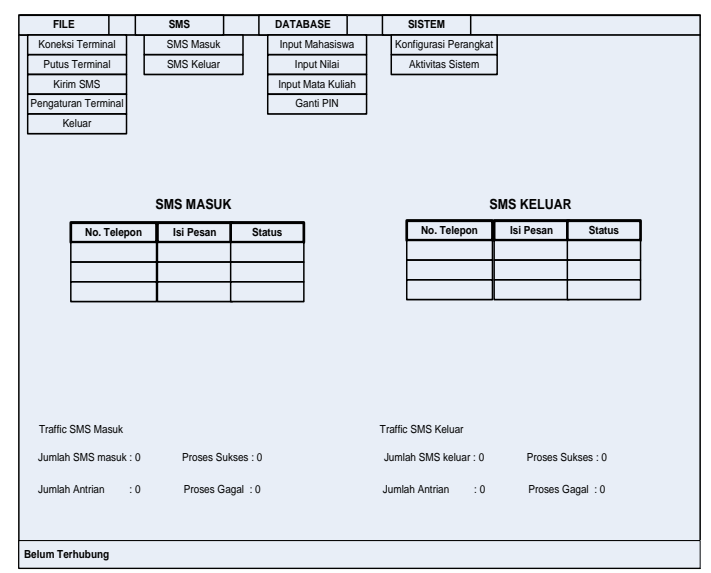

\subsection{Jendela Menu Utama}

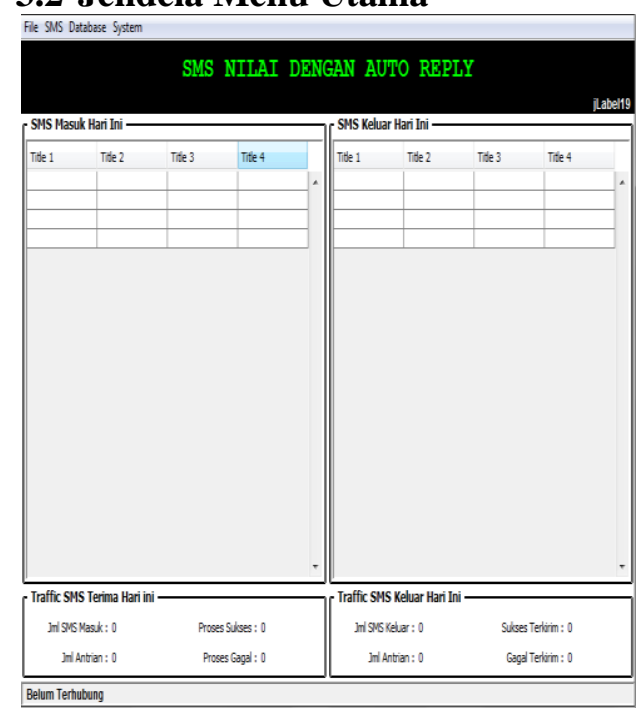

Gambar 3.2.1 Jendela Menu Utama
3.3 Jendela Kirim SMS Kirim SMS

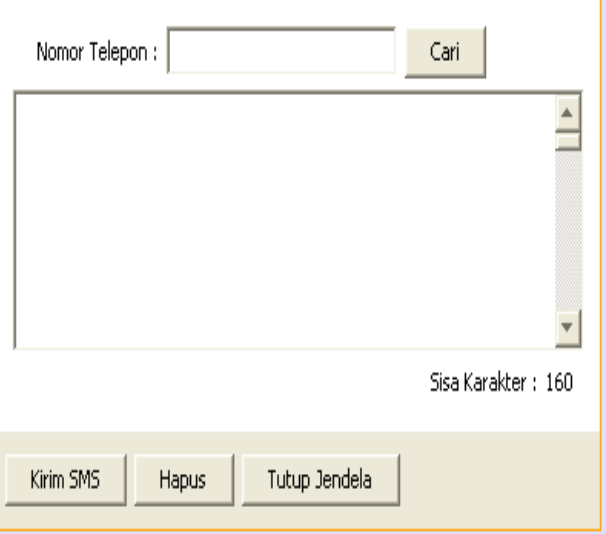

Gambar 3.3.1Jendela Kirim SMS

\subsection{Pengaturan Terminal}

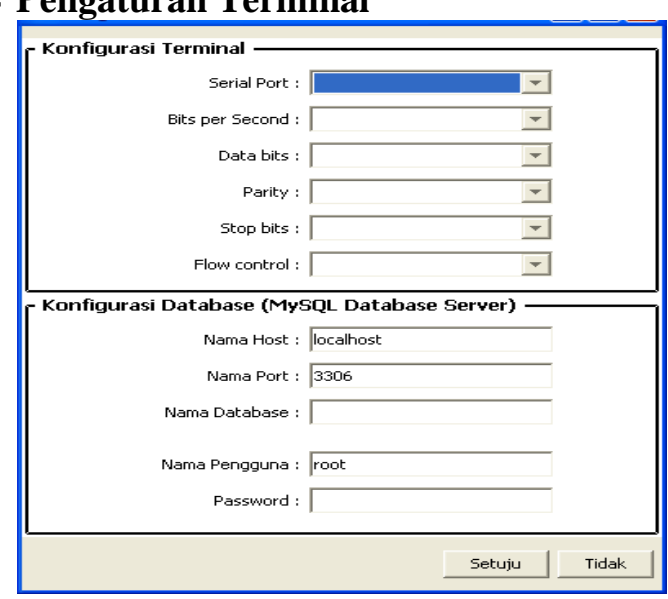

Gambar 3.3.2 Pengaturan Terminal

\subsection{Jendela Data SMS Masuk}

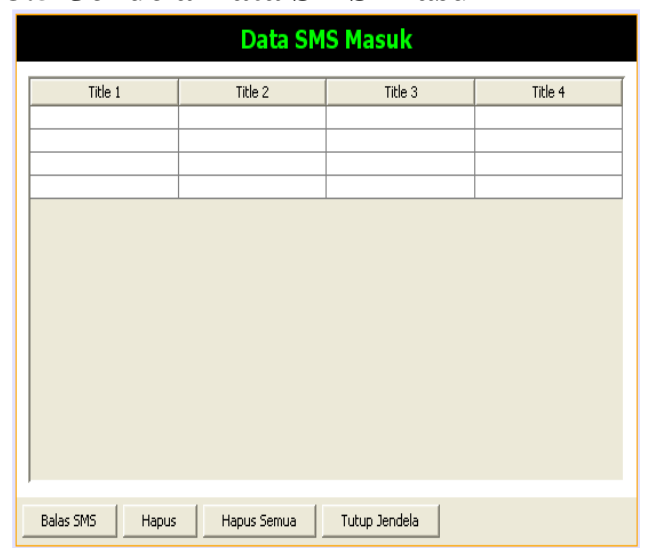

Gambar 3.5.1 Jendela Data SMS Masuk

\subsection{Jendela Data SMS Keluar}




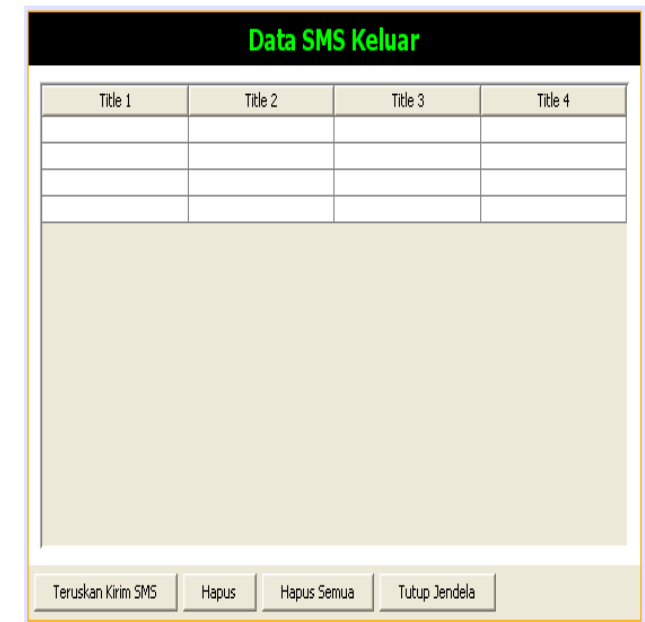

Gambar 3.6.1 Jendela Data SMS Keluar

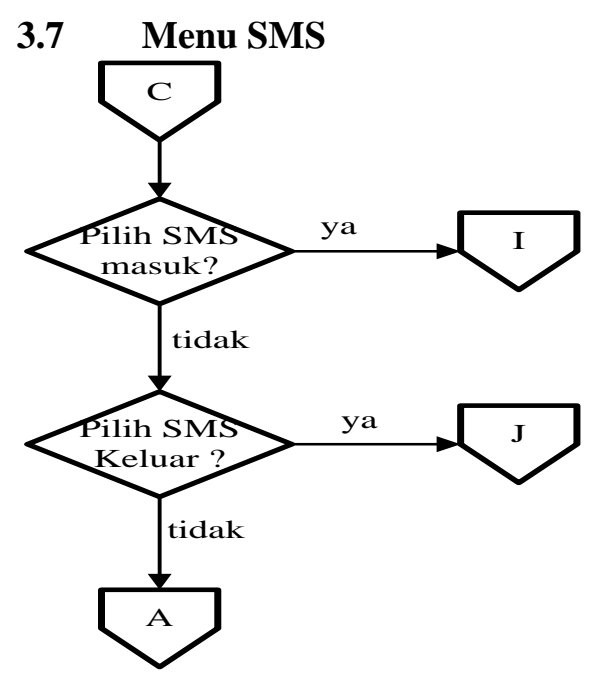

Gambar 3.7.1 Flowchart Menu SMS 3.8 Submenu SMS Masuk

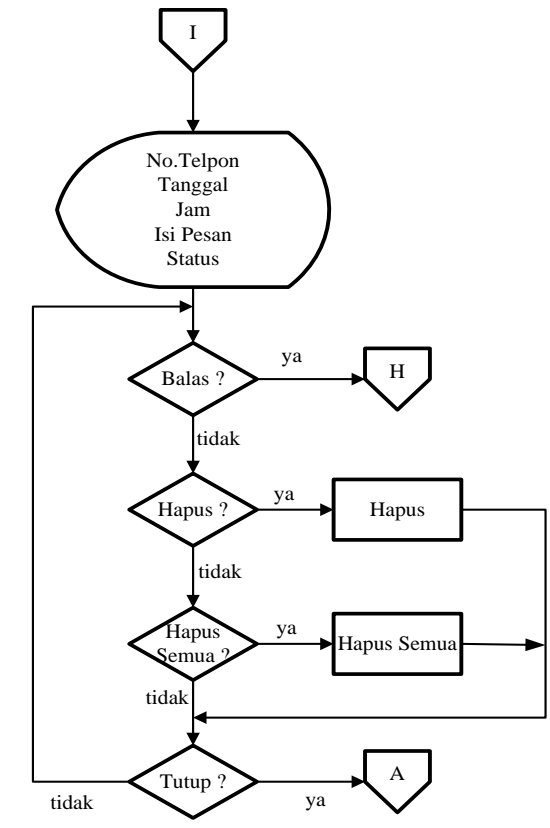

Gambar 3.8.1 Flowchart Submenu SMS Masuk

\subsection{Submenu SMS Keluar}

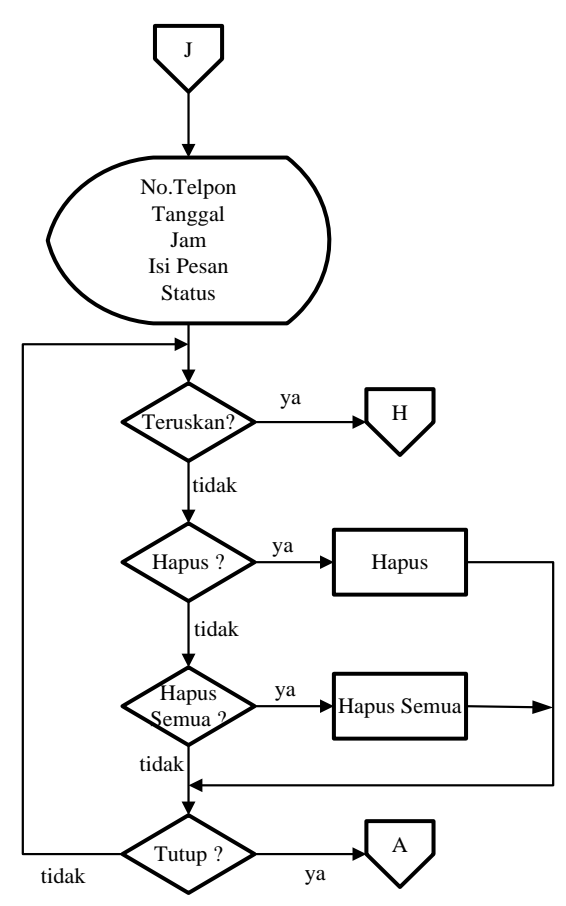

Gambar 4.24 Flowchart Submenu SMS Keluar

\section{SIMPULAN DAN SARAN 4.1 Simpulan}


Dari hasil penelitian ini dapat disimpulkan sebagai berikut:

1. sistem layanan sms nilai yang dibuat dengan menggunakan teori CRM

2. Karena jumlah mahasiswa sangat banyak, maka lalu lintas sms akan sangat banyak sehingga kecepatan akan sangat lambat

3. Pengembangan sistem sehingga aplikasi ini bisa berhubungan dengan database Universitas Bandar Lampung.

4. Pengembangan sistem agar sistem dapat memenuhi lebih banyak kebutuhan mahasiswa.

\section{DAFTAR PUSTAKA}

1. Adi Purnomo Pemrograman Java 2:Membangun Beragam Aplikasi Layanan SMS, penerbit Salemba Infotek, 2007

2. Jogiyanto, Analisis \& Desain Sistem Informasi, Penerbit Andi Yogyakarta : 2005

3. Tata Sutabri, Sistem Informasi Manajemen, Penerbit Andi Yogyakarta: 2005

4. Sri Hartati Wijono, B. Herry Suharto, Matius Soesilo Wijono, Pemrograman Java Servlet dan JSP dengan Netbeans, Penerbit Andi Yogyakarta: 2007

5. Romzi Imron.R, Membuat Sendiri SMS Gateway (ESME) Berbasis Protokol SMPP, Penerbit Andi Yogyakarta: 2006 